\title{
Oyun Terapisiyle Bütünleştirilmiş Grupla Psikolojik Danışmanın İlkokul Öğrencilerinin Sosyal Kaygı Düzeylerine Etkisi ${ }^{1}$
}

\author{
Esra TEKE ${ }^{2}$ ve Abdullah SÜRÜCÜ ${ }^{3}$
}

$\ddot{\mathrm{O} z}$

$\mathrm{Bu}$ araştırmanın amacı, oyun terapisiyle bütünleştirilmiş grupla psikolojik danışmanın ilkokul öğrencilerinin sosyal kayg1 düzeylerini azaltmadaki etkisinin incelenmesidir. Araştırmada, deneme modellerinden öntest-sontest kontrol gruplu deneysel desen kullanılmıştır. Bu araştırmanın çalışma grubunu, 2017-2018 eğitim öğretim y1lında Konya İli Selçuklu İlçesinde bulunan bir ilkokulun dördüncü sınıflarındaki öğrenciler olușturmaktadır. Araștırmanın bașında, dördüncü sınıfa devam eden öğrencilere ÇSAÖ-Y (Demir vd., 2000) uygulanmış, sosyal kaygı düzeyi en yüksek çıkan öğrenciler içinden yansız atama ile belirlenen sekiz öğrenci deney grubunu, sekiz öğrenci de kontrol grubunu oluşturmuştur. Araştırmada, deney grubuna sekiz grupla psikolojik danışma oturumu uygulanmıştır. Oturumlar sona erdikten sonra deney ve kontrol gruplarına (ÇSAÖ-Y) son test olarak tekrar uygulanmıştır. Deney ve kontrol grubunun öntest-sontest puanları arasındaki farklılık ve deney grubuna katılan öğrencilerin öntest ve izleme testi arasındaki farklılık Wilcoxon İşaretli Sıralar Testi ile test edilmiştir. Deney ve kontrol grubu öntest puanları ve sontest puanları arasındaki farklılık ise Mann Whitney U Testi ile test edilmiştir. Yapılan analiz sonucunda kontrol grubunun öntest-sontest puanları ile deney ve kontrol grubu öntest puanları arasında anlamlı bir farklılık bulunamamıștır. Deney grubu öntest-sontest puanları ile deney ve kontrol grubu sontest puanları arasında ise anlamlı bir farklılık bulunmuştur. Deney grubu öntest ve izleme testleri arasında da anlamlı farklılık bulunmuştur.

Anahtar Kelimeler: İlkokul Öğrencileri, Oyun Terapisi, Grupla Psikolojik Danışma, Sosyal Kayg1

\section{The Effects of Group Counseling Integrated with Play Therapy on Social Anxiety Levels} of Children at Primary School

\begin{abstract}
The aim of the study is to research the effect of group counseling integrated with play therapy on reducing the levels of social anxiety of primary school students. The study used an experimental "pretest-posttest" models. The research team of the study consists of fourth-grade pupil of elementary school located in the Selcuklu District of Konya Province of 2017 2018 academic year. At the beginning of the study, 8 pupils were applied to pupils with the highest level of social anxiety and were identified as an experimental group while another 8 were determined as the control group. All of them were pupils attending fourth grade ÇSAÖ-Y (Demir vd., 2000). In the study, eight groups of counseling sessions were applied to the experimental group. When the sessions were over, (ÇSAÖ-Y) the experimental and control groups were tested again. The difference between the scores before and after testing in the experimental and control groups, as well as the difference between the tests that passed the preliminary and subsequent tests, for students participating in the experimental group, were checked by Wilcoxon Signed Ranks Test. The difference between the scores before and after the experimental and control groups was tested by Mann-Whitney U-test. As a result of the analysis, no significant differences were found between the scores before and after testing the control group and the scores in the experimental groups. A significant difference was found between the scores obtained after testing in the experimental group and the scores after testing in the experimental and control groups. A significant difference was found between the preliminary tests in the experimental group and subsequent tests.
\end{abstract}

Key Words: Primary School Students, Play Therapy, Group Counseling, Social Anxiety

\section{Atıf İçin / Please Cite As:}

Teke, E. ve Sürücü, A. (2020). Oyun terapisiyle bütünleştirilmiş grupla psikolojik danışmanın ilkokul öğrencilerinin sosyal kayg1 düzeylerine etkisi. Manas Sosyal Arastirmalar Dergisi, 9(2), 695-708.

Geliş Tarihi / Received Date: 16.05.2019

Kabul Tarihi / Accepted Date: 12.06.2019

\footnotetext{
${ }^{1}$ Bu çalışma, Esra Teke'nin, Dr. Öğr. Üyesi Abdullah Sürücü danışmanlığında NEÜ Eğitim Bilimleri Enstitüsü Rehberlik ve Psikolojik Danışmanlık Bilim Dalında hazırlamıș olduğu yüksek lisans tezinden üretilmiştir.

2 Uzman Psk. Danışman - MEB Konya İl Milli Eğitim Müdürlüğü, esradogru_89@hotmail.com ORCID: 0000-0002-8436-2169

${ }^{3}$ Dr. Öğr. Üyesi - Necmettin Erbakan Üniversitesi AK Eğitim Fakültesi, asurucu@erbakan.edu.tr ORCID: 0000-0002-1689-4366
} 


\section{Giriş}

Kaygının, nedeni bilinmeyen bir sebepten ötürü hissedilen belirsiz korku, endişe ve sıkıntı ile ortaya çıktı̆̆ belirtilmektedir. Bireyde kötü bir şey olacağına ve bunu engelleyemeyeceğine ilişkin bir düşüncenin belirmesiyle kaygı meydana gelmektedir (Antony ve Swinson, 2017, s. 12). Çocukların, gelişim dönemleri içerisinde çeşitli kaygılar yaşadıkları görülmektedir. Ayrılık kaygısı, okula başlama, fiziksel yaralanma bunlardan bazılarıdır. Ayrıca, çocuğun yaşadığı ve önemle üzerinde durulması gereken bir kaygı türü de sosyal kaygıdır. Sosyal kayg1, olumsuz değerlendirilme korkusu ve sosyal ortamlarda duyulan sıkıntı ile karakterizedir (Albano, DiBartolo, Heimberg ve Barlow, 1995, s. 398).

Sosyal kayg1, bireyin kalabalık ortamlarda küçük duruma düşeceği kaygısının sebep olduğu, davranışsal, fizyolojik, somatik, bilişsel ve psikolojik belirtilerin ortaya çıktığı, kişinin işlevsellik düzeyinde büyük oranda düşüşe neden olan bir rahatsızlıktır (Bal, Çakmak ve Uğuz, 2013, s. 442). Sosyal kayg1 bozukluğu, değerlendirilme kaygisı olarak da ifade edilmektedir (Sapmaz, 2011, s. 25).

Sosyal kaygı yaşayan bireyler, başka insanların kendilerini yargıladığı ve negatif değerlendirdiği düşüncesi ile yetersizlik, aşağılanmışlık hisseder. Yanlış bir şey yapacak, söyleyecek ve sanki insanlar onunla alay edecek, onu yadırgayacak, aşağılayacak, herkesin içinde rezil olacak gibi hissederler. Konuşurken herkes ona bakıyormuş gibi gelir. Yaptıkları en ufak hatalar gözlerinde çok büyür, rezil olduklarını düşünürler. Sosyal kayg1 düzeyi yüksek olan bireylerde eleştirilmeye, olumsuz değerlendirilmeye, reddedilmeye aşırı duyarlılık, hakkını savunmada güçlük çekme, düşük benlik saygısı veya özgüven eksikliği de görülebilir (Sertelin-Mercan, 2007, s. 2).

Sosyal kaygı yaşayan bireylerde, davranışsal olarak kaçma, kaçınma, huzursuzluk, bulunduğu yerde donakalma, konuşma akışında bozukluk, koordinasyon bozukluğu görülebilmektedir. Bilişsel olarak, normal zihinsel süreç işlevlerinin ya abartılmış hale gelmesi ya da normal işlevlerin tahribatı söz konusu olabilmektedir. Fizyolojik olarak ise bu bireylerde, çarpıntı, kalp atım hızında artış, bayılma hissi, kaslarda gerginlik, reflekslerde artma, yorgunluk hissi ve çabuk yorulma, titreme, iştahsızlık, sık idrara çıma, terleme, ateş basması gibi belirtiler oluşabilmektedir (Yılmaz, 2013, s. 11). Sosyal kaygının aşırı olması, bireylerin, sosyal olarak kendisini geri çekmesine, sosyal ortamlardan kaçınmasına ve normal gelişim açısından önemli, yaşa uygun aktivitelerden uzaklaşmasına yol açabilir (La Greca, Dandes, Wick, Shaw ve Stone, 1988).

Sosyal kaygı, bireyin tepkilerinden dolayı ya tespit edilememekte ya da çok geç tespit edilmektedir. Bazen de tespit edildiği zaman çok geç olmaktadır. Bunun nedeni de sosyal kaygının toplumsal uyuma zarar veren özellikler olmaması, sadece bireyi içten içe kemiren bir özellikte olmasıdır. Kültürel olarak bakıldığında da, çevresini mutlu etmeye çalışan, olumsuz duygularını ifade edemeyen, sessiz, içe dönük bireylerin daha makbul olduğu algılanmaktadır. $\mathrm{Bu}$ da, sosyal kaygının tespitini ve sosyal kaygiya müdahaleyi geciktirmektedir. Okul ortamlarında sorun çıkarmayan, verilen görevleri yapmaya çalışan, olaylara tepkisiz öğrencilerin tespiti oldukça zordur.

Sosyal kaygıya etki eden etmenlerin sadece genetik yatkınlıkla açıklanamayacağı, bunun aynı zamanda çevresel faktörlerin de bir sonucu olduğu bilinmektedir. Çevresel faktörler aile, arkadaş ortamı, okul ve diğer sosyal ortamları kapsamaktadır. Yapılan çalışmalar kaygılı çocukların ebeveynlerini, çocukları üzerinde aşır1 kontrol kuran, fazla müdahaleci, yeterli şefkat ve sevgi gösteremeyen, fazla talepkar olarak tanımlamaktadırlar (Erkan, Güçray ve Çam, 2002, s. 72; Özyürek ve Demiray, 2010, s. 248; Yılmaz ve Duy, 2013, s. 70).

Çocuklara ilişkin gelişimsel çalışmalar, sosyal kaygının illkokul yıllarından başlayıp ergenlikte de süren önemli bir kaygı biçimi olduğunu göstermiştir (Demir, Eralp-Demir, Türksoy, Özmen ve Uysal, 2000, s. 43). Eren-Gümüş’e göre (2016, s. 64) çocuğun sosyal kayg1ya sahip olması ve bu problemin çözümlenmemesi, onun ileriki yaşamını önemli ölçüde etkilemektedir. Bu problemin erken fark edilmesi, erken dönemde verilecek olan psikolojik yardımın hem kısa hem de etkili olmasına daha çok yardımcı olacaktır.

Sosyal kaygı düzeyleri yüksek olan ve bu yüzden yaşamsal işlevleri aksayan çocuklarla yapılan çalışmalarda, bilişsel davranışçı tedavi yöntemler, oyun terapisi teknikleri olumlu sonuçlar verebilmektedir (Baggerly, 2004, s. 31; Knell, 2013, s. 324; Sezici, 2013, s. 1).

Okul çocuklarının yaşadıkları korku ve kaygı gibi sıkıntıların üstesinden gelmelerinde, olumsuz davranışlarını tecrübe edip bu davranışları düzenlemelerinde, içlerine attıkları olumsuz duyguları dışa vurmalarında ve yaşamla ilgili becerileri tecrübe etmelerinde oyun kolaylaştırıcı ve fayda sağlayıcı bir işleve 
sahiptir. Bu noktada oyunun pek çok yarar sağlayıcı işlevleri içerisinde, çocukların kaygılarıyla başa çıkmalarında ve buna yönelik beceriler kazanmalarında oyunun yarar sağlayıcı yönü dikkati çekmektedir (Doğanay, 1998, s. 1).

Oyun, normal çocukların gelişimine olumlu yönde etki yapmasının yanında terapötik bir etki de oluşturmaktadır (Schaefer ve Drewes, 2010, s. 15). Anna Freud, çocuklarla konuşmayı ve terapötik olarak iliş̧ki kurup sürdürmeyi, oyunun kolaylaştırdığından söz etmiştir (Halmatov, 2017, s. 12). Burns'e (2016, s. 37) göre de oyun ya da oyun etkinlikleriyle bir iyileştirme öyküsü oluşturulduğunda çeşitli terapötik faydalarda kendiliğinden ortaya çıkar. Oyunun çocuklara olumlu etkisini gören ruh sağllğı çalısanları, çocukların tedavi sürecinde oyunu kullanmak için oyun temelli yaklaşımları ortaya koymuşlardır. Böylece, çocukla kurulan terapötik iletişimde oyunun kullanılması, uzmanlar için kolaylaştırıcı bir nitelik oluşturmuştur (Schaefer ve Drewes, 2013, s. 22).

Oyun terapisi, bir çocuk ya da herhangi bir yetişkin birey ile oyun materyalleri ve oyun terapisi yöntemleri konusunda eğitim görmüş terapist arasında oyun yoluyla kurulan kendini ifade etme ve kendini keşfetmek (duygular, düşünceler, deneyimler ve davranışlar) amaçlarını da içeren, dinamik kişilerarası ilişkiler olarak tanımlanmaktadır (Landreth, 2012, s. 7). Oyun terapisi, istismar edilen, gelişimsel olarak geciken ve olumsuz davranışlar gösteren çocuklar için yaygın olarak kabul görmüş, bir tedavi modeli olarak kullanılmıştır (Leblanc ve Ritchie, 2001, s. 149). Oyun terapisinin çalış1ldığı ortak sorunlar arasında, sosyal veya akademik başarı eksikliği, uyku sorunları, ayrılma veya boşanma durumları, arkadaş edinme sorunları, zorbalık etmek, fiziksel, duygusal veya cinsel istismar dahil travma, kaybetme veya ölüm, bağlanma zorlukları, yeme bozuklukları, uygun olmayan duygusal tepkiler ve seçici konuşmama yer almaktadır (Robinson, 2011, s. 208). Literatür incelendiğinde, somatizasyon belirtileri gösteren çocuklarla da oyun terapisinin çalışıldığı görülmektedir (Schottelkorb, Swan, Jahn, Haas ve Hacker, 2015, s. 3).

Oyun terapisi ile uygulama yeterliliğine sahip ve çocukla çalışmak için gerekli becerileri edinmiş bir uzman, çocuğun güven içerisinde, baskıdan uzak olarak kendini anlatmasına olanak sunmuş olacaktır. Böylelikle kayg1 düzeyi yüksek olan çocuklar, bu güvenli ortam içerisinde kendilerini ifade edecek, kayg1 duydukları davranışları deneyimleyebilecek ve olumlu davranışlar kazanabileceklerdir (Doğanay, 1998, s. 1).

Oyun terapisi, kuramsal açıdan farklı yaklaşımlar tarafından ele alınmış ve açıklanmıştır. Bu yaklaşımlar genel olarak; "psikodinamik yaklaşımlar, hümanistik yaklaşımlar; sistemik yaklaşımlar, theraplay"dir (Schaefer, 2013, s. 11).

Gelişmekte olan yaklaşım olarak adlandırılan theraplay yaklaşımı içerisinde sayılan ve bu araştırma kapsamında uygulanan Bilişsel Davranışçı Oyun Terapisi (BDOT), okul öncesi ve erken dönem okul çağı çocukları için uygundur. Çocuğun terapiye katılımını vurgular; kontrol, yeterlilik ve kişinin kendi davranışını değiştirme sorumluluğu üzerine eğilir. Çocuğun, değişimde aktif bir katılımcı olmasına yardım edilir. Terapist, gelişimsel açıdan uygun müdahaleler sağlayarak çocuğun terapiye katılımını kolaylaştırır. BDOT içinde birçok davranışsal ve bilişsel müdahale birleştirilebilir. BDOT, çocuğun seansa kendiliğinden materyal getirmesine izin verirken yapılandırılmış ve amaç yönelimli etkinlikler sunar. Hem kendiliğinden ortaya çıkan materyal hem de daha yapılandırılmış etkinlikler, BDOT’nin başarısı açısından çok önemlidir (Knell, 2013, s. 325).

Oyun terapisinin ilkokulda kullanılması, bu dönem çocuklarının sorunlarına (kaygı, korku, çekingenlik, bağlanma problemleri, olumsuz davranışlar vb.) çözümler bulunmasını ve onların olumlu yönde gelişmesini (kendini ifade edebilme, olumlu davranışlar kazanabilme, iç görü sahibi olabilme vb.) sağlayabilmektedir (Landreth, 2012, s. 37). Yıldız'in (2015, s. 16) belirttiğine göre de ilköğretimde yapılan oyun terapisinin amacı, çocuğun o dönemdeki gelişimlerinin yerinde olup olmadığının anlaşılması ve eksik yönlerinin tamamlanmasıdır. Çünkü çocukların yaşamlarındaki en önemli uğraşılardan biri oyundur ve ilkokul çağındaki çocuklar için oyun ana gereksinimlerdendir. Çocukların bu gereksinimlerinin karşılanmaması halinde, sağlıklı olarak gelişip, büyümeleri beklenemez (Çankaya, 2014, s. 13). Oyun, çocuğun yeni şeyler öğrenme sürecine girmesine ve sağlıklı bir gelişim göstermesine katkıda bulunur (Burns, 2016, s. 38). Aynı zamanda oyun, çocuğun ruh sağlığı açısından ve psikolojik problemlerine çözümler bulması yönünden de önem arz eder. Bu nedenledir ki, oyunun tedavi aracı olarak kullanılması, istenilen amaca ulaşılabilmesi noktasında değerli bir adımdır (Bratton, Baggerly ve Ray, 2010, s. 181).

Zamanında çözümlenmeyen problemlerin ileride daha karmaşık ve kök salmış sıkıntılar olarak karşımıza çıktığı düşünüldüğünde, yaşanan zorlukların zamanında çözüme kavuşturulmasının önemi anlaşılabilir. Bu araştırmada, ilkokul dönemi öğrencilerinin yaşadıkları sorunların oyun terapisi yolu ile 
çözüme ulaştırılabilmesi için sosyal kayg1 yaşayan ilkokul öğrencilerine yönelik oyun terapisiyle bütünleştirilmiş grupla psikolojik danışma oturumları uygulanmıştır. "Oyun terapisiyle bütünleştirilmiş grupla psikolojik danışmanın ilkokul öğrencilerinin sosyal kaygı düzeylerine etkisi bulunmakta mıdır?” ifadesi bu araştırmanın problem cümlesini oluşturmaktadır.

Çocuklarda görülen problemlerde oyun terapisi uygulamalarına yönelik araştırmalar (Baggerly, 2004, s. 31; Knell, 2013, s. 324; Sezici, 2013, s. 1) bulunurken, sosyal kayg1 düzeyi yüksek çocuklarla yürütülen oyun terapisi çalışmasına alan yazında rastlanılmamıştır. Bu araştırmada, öğrencilerin sosyal kaygı düzeylerini azaltmak ve sosyal bir ortamda kendilerini ifade etmelerini sağlamak amaciyla oluşturulan oyun terapisi oturumları, okul rehber öğretmenlerinin sosyal kaygı yaşayan öğrencilere ulaşmalarına ve sorunlarına yardımc1 olmalarına katkı sağlayacaktır. Ayrıca, bu oturumlar ile öğrencilerin, sosyal kaygı düzeylerinin azalması sonrasında, ders sırasında potansiyellerini daha fazla kullanmaları sağlanacak, öğrencilerin akademik, sosyal ve duygusal gelişimine katkı sağlanmış olacaktır.

Türkiye'de yapılan yüksek lisans tezleri, doktora ve uzmanlık tezleri incelendiğinde, oyun terapisinin etkililiğini değerlendirmeye yönelik çalışmaların sınırlı olduğu görülmektedir. Bu anlamda da, oyun terapisinin etkililiğini değerlendirmek ve buna yönelik çalısmaların sayısını arttırmak açısından bu çalışmanın önemli olduğu düşünülmektedir.

\section{Amaç}

$\mathrm{Bu}$ araştırmanın amacı, oyun terapisiyle bütünleştirilmiş grupla psikolojik danışmanın, ilkokul öğrencilerinin sosyal kaygı düzeyleri üzerindeki etkisini incelemektir. Bu amaç doğrultusunda, aşağıdaki denenceler test edilmiştir.

1. Deney ve kontrol grubunda bulunan öğrencilerin, ÇSAÖ-Y öntest puanları arasında istatistiksel olarak anlamlı bir fark yoktur.

2. Deney grubunda bulunan öğrencilerin, ÇSAÖ-Y öntest-sontest puanları arasında istatistiksel olarak anlamlı bir fark vardır.

3. Kontrol grubunda bulunan öğrencilerin, ÇSAÖ-Y öntest-sontest puanları arasında istatistiksel olarak anlamlı bir fark yoktur.

4. Deney ve kontrol grubunda bulunan öğrencilerin, ÇSAÖ-Y sontest puanları arasında istatistiksel olarak anlamlı bir fark vardır.

5. Deney grubunda bulunan öğrencilerin ÇSAÖ-Y ön test puanları ile ÇSAÖ-Y izleme testi puanları arasında istatistiksel olarak anlamlı bir fark vardır.

\section{Yöntem}

$\mathrm{Bu}$ araştırma, oyun terapisiyle bütünleştirilmiş grupla psikolojik danışmanın, ilkokul öğrencilerinin sosyal kayg1 düzeyleri üzerindeki etkisini inceleyen deneme modelinde yürütülmüştür. Araştırmada, "öntest-sontest kontrol gruplu” deneysel desen kullanılmıştır. Öntest-sontest kontrol gruplu model, yansız atama ile oluşturulmuş deney ve kontrol gruplarından oluşan, her iki grupta deney öncesi ve sonrası ölçmeler yapılan gerçek deneme modelidir (Karasar, 2009, s. 97). Araştırmada deney grubuna, oyun terapisiyle bütünleştirilmiş grupla psikolojik danışma oturumları (sekiz oturum) uygulanmıştır. Araştırmanın bağımsız değişkeni oyun terapisi ile bütünleştirilmiş grupla psikolojik danışma oturumları, bağımlı değişkeni ise ilkokul öğrencilerinin sosyal kaygı düzeyleridir.

\section{Çalışma Grubu}

Bu araştırmanın çalışma evrenini, 2017-2018 eğitim öğretim yllında Konya İli Selçuklu İlçesinde bulunan bir ilkokulda dördüncü sınıfta okuyan öğrenciler oluşturmaktadır. Çalışma evrenindeki 99 öğrencinin 54’ü $(\% 54,5)$ kız, 45’i $(\% 45,5)$ erkektir. Öğrencilere, araştırmanın başında ÇSAÖ-Y (Demir vd., 2000, s. 44) uygulanmıştır. Kız öğrencilerin ÇSAÖ-Y aldıkları minimum puan 23 , maksimum puan ise 80 ve ortalamaları 42'dir. Erkek öğrencilerin ÇSÄ̈-Y aldıkları minimum puan 19, maksimum puan ise 72 ve ortalamaları 41'dir. Buna göre sosyal kaygı düzeyi en yüksek çıkan öğrenciler içinden yansız atama yöntemi ile belirlenen dörder kız, dörder erkek olmak üzere sekiz öğrenci deney grubunu, sekiz öğrenci de kontrol grubunu oluşturmuştur. Araştırmada, deney ve kontrol grupları öğrencilerin cinsiyetleri, yaşları, kardeş sayıları, ekonomik durumları, aile yapılanı ve anne baba birliktelik durumları yönünden eşitlenmiştir. Öğrenciler, dokuz yaşında, kardeş sayıları iki-üç, ekonomik durumları 1000-2000 TL'dir. Öğrencilerin aileleri çekirdek aile yapısına sahip ve anne babaları birliktedir. 


\section{Veri Toplama Araçları}

Araştırma verileri, Kişisel Bilgi Formu ve Çocuklar İçin Sosyal Anksiyete Ölçeği-Yenilenmiş Form (ÇSAÖ-Y) kullanılarak toplanmıştır.

Araştırmacı tarafindan geliştirilen, öğrencilere ilişkin sosyo-demografik bilgileri elde etmek amacıyla kullanılan Kişisel Bilgi Formu, dokuz maddeden oluşmaktadır. Cinsiyet, yaş, kardeş sayısı, anne eğitim durumu, baba eğitim durumu, ailenin ekonomik durumu, aile yapısı, okul başarı düzeyi ve anne baba birliktelik durumu ile ilgili bilgileri içermektedir.

La Greca vd. (1988) tarafından geliştirilen, öz bildirime dayalı olan Çocuklar için Sosyal Anksiyete Ölçeği-Yenilenmiş Biçim (ÇSAÖ-Y) (Social Anxiety Scale for Children-Revised)'nin geçerlilik ve güvenilirlik çalışması Demir vd. (2000, s. 43) tarafindan yapılmıştır. Ölçek, 1993 yılında gözden geçirilerek 18 soruluk bir ölçeğe dönüştürülmüştür. Maddelerin hazırlanmasında sosyal kaygının iki bileşeni, olumsuz değerlendirilme korkusu ve sosyal ortamlarda duyulan sıkıntı, rahatsızlık temel alınmıştır. Beş dereceli likert tipi yanıtlanan, öz bildirime dayalı bu ölçekte puanlar 18-90 arasındadır. ÇSAÖ-Y'nin Türkçe'de geçerlilik ve güvenirlilik çalışması, 4-8. sınıflara devam eden 452 öğrencinin katılımı ile yapılmıştır. Ölçeğin iç tutarll1ık Cronbach alfa katsayıs $\alpha=0.813$ olarak bulunmuştur. Ölçek, ilk uygulamadan bir ay sonraki test tekrar test korelasyonu ise $\mathrm{r}=0.81$ olarak bulunmuştur. Tek tek maddelerin birbiriyle test-tekrar test korelasyonlan $\mathrm{r}=0,346$ ile 0,552 arasında değişmekte olduğu görülmüştür. Ölçüt bağıntıll geçerliliğin (uyum geçerliliği) sınanması için Çocuklar için Sürekli Kaygı Envanteri uygulanmıştır. Bu ölçekle ÇSAÖ-Y iyi bir korelasyon göstermektedir $(\mathrm{r}=0,5975, \mathrm{p}<0.001)$. Geçerlilik çalışması kliniğe başvurmuş sosyal fobi olgularıyla yapılmış, ölçeğin olguları normal kontrollerden ayırt edebildiği görülmüştür. ÇSAÖ-Y, çocuk ve ergenlerde sosyal kayg1yı ölçmek için geçerli ve güvenilir bir araç olarak görülmektedir.

\section{İşlem}

Eckhardt ve Ermann'a göre öntest-sontest kontrol gruplu desenin gereklerinden biri, desenin bir denek havuzuna sahip olması ve bu havuzdan seçilen deneklerin yansız (seçkisiz) atama ile iki gruba ayrılmasıdır (Akt: Sapmaz, 2011, s. 61). Bundan dolayı araştırmada yer alan deneklerin tespiti için öncelikle denek havuzu oluşturulmuştur. Bu amaçla, 2017-2018 eğitim öğretim yılı Konya İli Selçuklu İlçesindeki bir ilkokulda öğrenim gören dördüncü sınıf öğrencilerinin tamamına öntest olarak ÇSAÖ-Y araştırmac1 tarafindan uygulanmıştır.

Ölçeğin sağlıklı bir şekilde uygulanabilmesi için öğrenciler 10’ar kişilik gruplar halinde okulda bulunan oyun odasına alınmış ve ölçekler, araştırmacının gözetiminde, açıklamalar yapılarak öğrencilere doldurtulmuştur. Kişisel Bilgi Formu ve ölçeklerin doldurulması 15-20 dakika sürmüştür. Ölçeklerin, okulun dördüncü sınıflarındaki öğrencilerinin tamamına uygulanması üç gün sürmüştür.

Ölçeklerin uygulanmasının ardından her bir öğrencinin almış olduğu puan hesaplanmış ve bu puanlar sıralanmıştır. Buna göre, ölçekten alınan en düşük puan 18, en yüksek puan ise 80 olarak tespit edilmiştir. Ölçek puanlarının değerlendirilmesinde, ölçeği geliştiren uzman görüşü de alınarak 59 puan ve üzeri alan öğrenciler, araştırmanın denek havuzunu oluşturmuştur. Ayrıca, sınıf öğretmenlerinin ve öğrenci ailelerinin de görüşleri alınarak sosyal kaygı düzeyi yüksek olabilecek öğrenciler netleştirilmiştir. Kişisel bilgi formundan elde edilen bilgiler (cinsiyet, yaş, kardeş sayısı, ekonomik durum, aile yapısı ve anne baba birliktelik durumu) de dikkate alınarak 16 ögrenci belirlenmiştir. Öğrenciler, seçkisiz olarak deney ve kontrol gruplarına atanmıştır. Seçkisiz atama yapılırken öğrencilerin, anket numaraları küçük kâğıtlara yazılmış ve torbaya konmuştur. Ardından öğrencilerin numaralarının bulunduğu kâğıtlar torbadan kura yöntemi ile çekilerek iki grubun listesi oluşturulmuştur. Son olarak bu iki grup, kura yöntemiyle seçkisiz olarak deney ve kontrol grubu olarak belirlenmiştir. Sonuçta deney grubunda sekiz (dört kız, dört erkek), kontrol grubunda sekiz (dört kız, dört erkek) öğrenci yer almıştır.

Deney grubuna, sosyal kayg1 yaşayan ilkokul öğrencilerine yönelik oyun terapisiyle bütünleştirilmiş grupla psikolojik danışma oturumları (sekiş oturum) uygulanmıştır. Oturumlar, araştırmacı tarafından hazırlanmıştır. Araştırmacı, yüksek lisansta oyun terapisine giriş dersi almış, oyun terapisi ile ilgili eğitimlere ve atölye çalışmalarına katılmışıır. Ayrıca, araştırmacı bu süreçte bilişsel davranışçı terapi teknikleri ve ileri düzeyde bilişsel davranışçı terapi tekniklerinin uygulanması dersleri alarak, çocuklarda görülen sorunların çözümlerinde bilişsel davranışçı terapi tekniklerinin uygulanması atölye çalısmalarına da katılmışır.

Sosyal kayg1 düzeyleri yüksek olan ve bu yüzden yaşamsal işlevleri aksayan çocuklarla yapılan çalışmalarda, bilişsel davranış̧̧ tedavi yöntemleri, oyun terapisi teknikleri olumlu sonuçlar verebilmektedir 
(Baggerly, 2004, s. 31; Knell, 2013, s. 324; Sezici, 2013, s. 58). Buradan hareketle sosyal kayg1ya yönelik olarak yapılmış daha önceki çalışmalar incelenmiş ve oturumların oluşturulmasında oyun terapisi ve bilişsel davranışçı yaklaşıma dayalı grup oturumları temel alınmıştır (Koçkaya, 2016, s. 37; Sapmaz, 2011, s. 10; Sertelin-Mercan, 2007, s. 100; Sezici, 2013, s. 58; Yıldız, 2015, s. 24). Ayrıca oturumların oluşturulmasında öğrencilerin yaş seviyesi, gelişimsel özellikleri de göz önünde bulundurulmuştur.

Birinci oturumda, "Grup üyeleriyle tanışma, konuşurken karşıdaki kişinin yüzüne bakabilme ve dikkatle dinleyebilme, grup kurallarını oluşturma ve bu kurallara uyma konusunda ortak bir anlayış geliştirebilme, grup yaşantısı içinde ulaşılmak istenen bireysel hedefler belirleyebilme" hedeflerine yönelik olarak, tanışma etkinliği yapılmış, "isim oyunu" (Kaya ve Saçkes, 2012, s. 149) oynanmıştır. İçinde bazı şeylerin olduğu bir torbanın içindeki nesneleri hissedip tarif etmeleri istenmiştir (Sümer, 2012). İkinci oturumda, "Kayg1 düzeyinin kişisel değerlendirmesini yapabilme, kaygıya eşlik eden fizyolojik, duygusal, davranışsal, zihinsel belirtileri fark edebilme kendi sosyal kaygı öyküsünü fark edebilme" hedeflerine yönelik olarak, sosyal kayg1 yaşayan "üç kuklanın öyküsü" (Yazman, t.y.) anlatılmış ve öykü kuklalarla canlandırılmıştır. Kayg1 düzeylerinin kişisel olarak değerlendirilmesine yönelik olarak da "kişisel değerlendirme tekniği" (Stickney, 2017, s. 123) uygulanmıştır. Ücüncü oturumda, "Olaylar karşısındaki farklı bakış açılarını fark edebilme, düşünce-duygu-davranış bağını fark edebilme" hedeflerine yönelik olarak, "lensler" (Linden, 2017b, s. 270) etkinliği uygulanmış ve ardından "ziyaretçi" (Liberman, 2015) masalı anlatılmıştır. Masalın anlatımı sırasında kuklalar kullanılmıştır. Dördüncü oturumda, "Kayg1 durumunda oluşan fiziksel tepkileri fark edebilme, kayg1 durumunda oluşan fiziksel tepkileri kontrol edebilme, kontrollü nefes alıp verebilme" hedefine yönelik olarak "rahatlama eğitimi: baloncuklar" (Cabe, 2017, s. 349) etkinliği uygulanmıştır. Çocuklara kova resmi çizilmiş kâğıtlara o anda hissettikleri kaygı duygusunun seviyesini çizmelerini istenmiştir.

Beşinci oturumda, "Duygu ve düşüncelerini fark edebilme, alternatif düşünceler geliştirebilme, bedensel belirtileri somutlaştırabilme, kaygıyla yüzleşebilme, yeni davranışlar edinebilme" hedeflerine yönelik olarak "kuklalarla psikodrama" (Sprague, 2017, s. 237) ile "sosyal fobi ve bir psikodrama uygulaması"1ndan (Yerlikaya, 2011) yararlanılarak etkinlik gerçekleştirilmiştir. Altınc oturumda, "Kaygıllarıyla kademeli olarak tehdit edici olmayan bir şekilde yüzleşebilme, bastırılmış duyguları ortaya çıkarabilme, olumlu güçleri üzerinde odaklanabilme" hedeflerine yönelik olarak "parti şapkalı canavarlar" (Crenshaw, 2017, s. 110) etkinliğinden yararlanılmıştır. Yedinci oturumda, "Duyguları tanıyabilme ve ayırt edebilme, olumlu ve olumsuz duygu ve düşüncelerin kendi üzerindeki etkisini fark edebilme" hedefine yönelik olarak "duygu" (Halmatov, 2017, s. 12) oyunu oynanmıştır. Çocuklara yaşadığımı duygularla birlikte olumlu ya da olumsuz bazı düşünceler taşıdığımız ve bunun yaşamımızı etkilediğinden bahsedilerek "ağırlıklar ve balonlar" (Linden, 2017a, s. 270) etkinliği uygulanmıştır. Sekiz̨inci oturumda, "Katılımcıların gruptan ayrılmadan kendileri ile ilgili olumlu geri bildirimler almalarını sağlamak" hedefine yönelik olarak "Verandadaki salıncakta okuma" (Doherty ve Philips, 2017, s. 36) etkinliğini yapılmıştır. Ardından "sevgi bombardımanı" (Acar, 2013) etkinliği uygulanmıştır.

Her oturum, 40 dakika olarak planlanmış ve oturumlar haftada bir kez gerçekleştirilmiştir. Tüm çalışma grubu oturumların tamamına katılmıştır. Öğrencilerin çalışmaya katılımda istekli oldukları görülmüştür. Oturumlar iki ay süreyle uygulanmıştır. Oturumların tamamlanmasının ardından deney ve kontrol grubuna sontest uygulanmıştır. Araştırmadan altı ay sonra beşinci sınıfa geçen ve farklı ortaokullarda eğitim öğretime devam eden deney grubu öğrencilerine izleme çalışması yapılmıştır.

\section{Verilerin Analizi}

Araştırma verilerinden, deney ve kontrol grubunda bulunan öğrencilerin ÇSAÖ-Y öntest-sontest puanları arasındaki farkllık ve deney grubuna katılan öğrencilerin öntest-izleme testi arasındaki farklılık Wilcoxon İşaretli Sıralar Testiyle analiz edilmiştir. Deney ve kontrol grubuna katılan öğrencilerin ÇSAÖ-Y öntest puanları arasındaki farkl1l1k ve sontest puanları arasındaki farkll11k Mann Whitney U Testiyle hesaplanmıştır. Deney grubuna katılan öğrencilerin ÇSAÖ-Y öntest-sontest puanları arasındaki farklılık ise Kruskal Wallis Testiyle analiz edilmiştir.

\section{Bulgular}

Araştırmada elde edilen veriler, denenceler doğrultusunda test edilmiş ve ulaşılan sonuçlar tablolar halinde gösterilmiştir.

Denence 1: Deney ve kontrol grubunda bulunan öğrencilerin, ÇSAÖ-Y öntest puanları arasında istatistiksel olarak anlamlı bir fark yoktur. 
Araştırma verilerinin analizleri sonucunda deney ve kontrol grubuna katılan öğrencilerin ÇSAÖ-Y öntest puanlarına ait Mann Whitney U Testi sonuçları Tablo 1'de verilmiştir.

Tablo 1. Deney ve Kontrol Grubunun CSAÖ-Y Öntest Puanlarna Illişkin Mann Whitney U Testi Sonuclar

\begin{tabular}{lccccc}
\hline Puan & $\boldsymbol{N}$ & $\begin{array}{c}\text { Sira } \\
\text { Ortalamas }\end{array}$ & Sira Toplami & $\boldsymbol{U}$ & $\boldsymbol{P}$ \\
\hline $\begin{array}{l}\text { Deney Grubu Öntest } \\
\text { Puanı }\end{array}$ & 8 & 9,44 & 75,50 & 24,500 & 0,442 \\
$\begin{array}{l}\text { Kontrol Grubu Öntest } \\
\text { Puanı }\end{array}$ & 8 & 7,56 & 60,50 & & \\
\hline $\mathrm{p}<, 05$ & &
\end{tabular}

Deney ve kontrol grupları birbirinden bağımsız gruplar olduğu için bu iki grubun öntest puanları arası fark olup olmadığının analizi Mann Whitney U Testi ile yapılmıştır. Mann Whitney U Testi sonuçları doğrultusunda deney ve kontrol grubunda bulunan öğrencilerin ÇSAÖ-Y öntest puanları arasında anlamlı bir farklılık bulunamamı̧tır $(\mathrm{U}=24,500 ; \mathrm{p}<, 05)$.

Denence 2: Deney grubunda bulunan öğrencilerin ÇSAÖ-Y öntest-sontest puanları arasında istatistiksel olarak anlamlı bir fark vardır.

Araştırma verilerinin analizleri sonucunda deney grubuna katılan öğrencilerin ÇSAÖ-Y öntest-sontest puanlarına ait Wilcoxon İşaretli Sıralar Testi Sonuçları Tablo 2'de verilmiştir.

Tablo 2. Deney Grubunun CSAÖ-Y Öntest-Sontest Puanlarna Ilisskin Wilcoxon Ișaretli Siralar Testi Sonuclar

\begin{tabular}{|c|c|c|c|c|c|c|}
\hline Deney Grubu & Siralar & $N$ & $\begin{array}{c}\text { Sita } \\
\text { Ortalamas1 }\end{array}$ & $\begin{array}{c}\text { Sira } \\
\text { Toplam1 }\end{array}$ & $z$ & $P$ \\
\hline $\begin{array}{l}\text { Sosyal Kayg1 Öntest } \\
\text { Puanı }\end{array}$ & $\begin{array}{l}\text { Negatif Siralar } \\
\text { Pozitif Siralar }\end{array}$ & 8 & 4,50 & 36,00 & & \\
\hline $\begin{array}{l}\text { Sosyal Kayg1 Sontest } \\
\text { Puanı }\end{array}$ & $\begin{array}{l}\text { Eşit } \\
\text { Toplam }\end{array}$ & $\begin{array}{l}0 \\
8\end{array}$ &, 00 &, 00 & $-2,521$ & $0,012^{*}$ \\
\hline
\end{tabular}

$\mathrm{p}<, 05$

Deney grubunu oluşturan öğrencilerin ÇSAÖ-Y'den aldıkları öntest ve sontest puanları arasında anlamlı bir farklılık bulunup bulunmadı̆̆ını test etmek için yapılan Wilcoxon İşaretli Sıralar Testi sonucunda sıra ortalamaları arasındaki fark istatistiksel olarak anlamlı bulunmuştur. Tablo 2'de görüldügü üzere deney grubunu oluşturan öğrencilerin ÇSAÖ-Y'den aldıkları öntest ve sontest puanları arasında istatiksel açıdan anlamlı farklılık vardır $(\mathrm{z}=-2,521 ; \mathrm{p}<, 05)$. Fark puanlarının sıra ortalaması ve sıra toplamları göz önünde bulundurulduğunda bulgulanan bu farklilığın sonucunda sontest lehine azalma olduğu görülmektedir.

Denence 3: Kontrol grubunda bulunan öğrencilerin ÇSAÖ-Y öntest-sontest puanları arasında istatistiksel olarak anlamlı bir fark yoktur.

Araştırma verilerinin analizleri sonucunda kontrol grubuna katılan öğrencilerin ÇSAÖ-Y öntestsontest puanlarına ait Wilcoxon İşaretli Sıralar Testi sonuçları Tablo 3'de verilmiştir.

Tablo 3. Kontrol Grubunun CSAÖ-Y Öntest-Sontest Puanlarnna Ilişkin Wilcoxon İsaretli Siralar Testi Sonuclarn

\begin{tabular}{|c|c|c|c|c|c|c|}
\hline Kontrol Grubu & Siralar & $N$ & $\begin{array}{c}\text { Sira } \\
\text { Ortalamasi } \\
\end{array}$ & $\begin{array}{c}\text { Sira } \\
\text { Toplami } \\
\end{array}$ & $z$ & $P$ \\
\hline \multirow{2}{*}{$\begin{array}{l}\text { Sosyal Kayg1 Öntest } \\
\text { Puanı }\end{array}$} & Negatif Siralar & 6 & \multirow{2}{*}{3,83} & \multirow{2}{*}{23,00} & \multirow{5}{*}{$-0,704$} & \multirow{5}{*}{0,481} \\
\hline & Pozitif Siralar & 2 & & & & \\
\hline \multirow{3}{*}{$\begin{array}{l}\text { Sosyal Kayg1 Sontest } \\
\text { Puanı }\end{array}$} & & & & & & \\
\hline & Eşit & 0 & \multirow{2}{*}{6,50} & \multirow{2}{*}{13,00} & & \\
\hline & Toplam & 8 & & & & \\
\hline
\end{tabular}


Kontrol grubunu oluşturan öğrencilerin ÇSAÖ-Y'den aldıkları öntest ve sontest puanları arasında anlamlı bir farklılık bulunup bulunmadığını test etmek için yapılan Wilcoxon İşaretli Sıralar Testi sonucunda sıra ortalamaları arasındaki fark istatistiksel olarak anlamlı bulunmamıştır. Tablo 3'de gösterildiği üzere kontrol grubunu oluşturan öğrencilerin ÇSAÖ-Y’den aldıkları öntest ve sontest puanları arasında istatiksel açıdan anlamlı bir fark yoktur $(z=-0,704 ; p>, 05)$.

Denence 4: Deney ve kontrol grubunda bulunan öğrencilerin, ÇSAÖ-Y sontest puanları arasında istatistiksel olarak anlamlı bir fark vardır.

Araştırma verilerinin analizleri sonucunda deney ve kontrol grubuna katılan öğrencilerin ÇSAÖ-Y sontest puanlarına ait Mann Whitney U Testi sonuçları Tablo 4'de verilmiştir.

Tablo 4. Deney ve Kontrol Grubunun CSAÖ-Y Sontest Puanlarna İliskin Mann Whitney U Testi Sonucları

\begin{tabular}{lccccc}
\hline Puan & $\boldsymbol{N}$ & $\begin{array}{c}\text { Sira } \\
\text { Ortalamas1 }\end{array}$ & $\begin{array}{c}\text { Sira } \\
\text { Toplami }\end{array}$ & $\boldsymbol{U}$ & $\boldsymbol{P}$ \\
\hline $\begin{array}{l}\text { Deney Grubu Sontest } \\
\text { Puan1 }\end{array}$ & 8 & 4,69 & 37,50 & & $0,001^{*}$ \\
$\begin{array}{l}\text { Kontrol Grubu Sontest } \\
\text { puan1 }\end{array}$ & 8 & 12,31 & 98,50 & 1,500 & \\
\hline $\mathrm{p}<, 05$ & & & &
\end{tabular}

Deney ve kontrol grupları birbirinden bağımsız gruplar olduğu için bu iki grubun sontest puanları arası fark olup olmadı̆̆ının analizi Mann Whitney U Testi ile yapılmıştır. Mann Whitney U Testi sonuçları doğrultusunda deney ve kontrol grubunda bulunan öğrencilerin ÇSAÖ-Y sontest puanları arasında anlamlı bir farklilik olduğu bulunmuştur $(\mathrm{U}=1,500 ; \mathrm{p}<, 05)$.

Denence 5: Deney grubunda bulunan öğrencilerin ÇSAÖ-Y ön test puanları ile ÇSAÖ-Y izleme testi puanları arasında istatistiksel olarak anlamlı bir fark vardır.

Araştırma verilerinin analizi sonucunda deney grubuna katılan öğrencilerin ÇSAÖ-Y öntest puanları ile izleme test puanları arasındaki farka ilişkin Wilcoxon İşaretli Sıralar Testi sonuçları Tablo 5'de verilmiştir.

Tablo 5. Deney Grubunda Bulunan Öğrencilerin CSAÖ-Y Öntest ve CSAÖ-Y İzleme Testi Puanlarna İlişkin Wilcoxon Issaretli Siralar Testi Sonuclar

\begin{tabular}{|c|c|c|c|c|c|c|}
\hline Deney Grubu & Siralat & $N$ & $\begin{array}{c}\text { Sita } \\
\text { Ortalamasi } \\
\end{array}$ & $\begin{array}{c}\text { Sira } \\
\text { Toplam1 } \\
\end{array}$ & $z$ & $P$ \\
\hline \multirow{2}{*}{$\begin{array}{l}\text { Sosyal Kayg1 Öntest } \\
\text { Puanı }\end{array}$} & Negatif Siralar & 0 & \multirow{2}{*}{4,50} & \multirow{2}{*}{36,00} & & \\
\hline & Pozitif Siralar & 8 & & & & \\
\hline \multirow{3}{*}{$\begin{array}{l}\text { Sosyal Kayg1 } \\
\text { İzleme Testi Puanı }\end{array}$} & & & \multirow{3}{*}{0,00} & & $-2,521$ &, $012^{*}$ \\
\hline & Eşit & 0 & & \multirow{2}{*}{0,00} & & \\
\hline & Toplam & 8 & & & & \\
\hline
\end{tabular}

$\mathrm{p}<, 05$

Deney grubunu oluşturan öğrencilerin ÇSAÖ-Y'den aldıkları öntest ve izleme puanları arasında anlamlı bir farklılık bulunup bulunmadığını test etmek için yapılan Wilcoxon İşaretli Sıralar Testi sonucunda sıra ortalamaları arasındaki fark istatistiksel olarak anlamlı bulunmuştur. Tablo 5'de görüldüğü üzere deney grubunu oluşturan öğrencilerin ÇSAÖ-Y'den aldıkları öntest ve izleme puanları arasında istatiksel açıdan anlamlı farklılık vardır $(\mathrm{z}=-2,521 ; \mathrm{p}<, 05)$. Fark puanlarının sıra ortalaması ve sira toplamları göz önünde bulundurulduğunda bulgulanan bu fark soncunda izleme testi lehine azalma olduğu görülmektedir.

\section{Tartışma, Sonuç ve Öneriler}

Bu araștırmada, oyun terapisiyle bütünleştirilmiş grupla psikolojik danışmanın, ilkokul öğrencilerinin sosyal kaygı düzeylerini azaltmadaki etkisi incelenmiştir. Araştırma verilerinin analizinden elde edilen istatistiksel sonuçlar denencelere göre tartışılmış ve yorumlanmıştır.

Denence 1: Deney ve kontrol grubunda bulunan öğrencilerin, ÇSAÖ-Y öntest puanları arasında istatistiksel olarak anlamlı bir farklılığın olmadığına dair bulguların tartışılması ve yorumlanması: 
Verilerin analizine göre, deney ve kontrol grubuna katılan öğrencilerin ÇSAÖ-Y öntest puanları arasında istatistiksel olarak anlamlı bir farkllık yoktur. Bu durum, oyun terapisiyle bütünleştirilmiş grupla psikolojik danışma oturumlarına başlarken deney ve kontrol grubunda bulunan öğrencilerin kayg1 düzeylerinin benzer seviyede olduğunu göstermektedir.

Saltık (2018), kadın konukevlerinde kalan çocuklarda, oyun terapisinin sosyal beceri ve problem davranışlarına etkisini incelenmek üzere yaptığı araştırmada, 3-6 yaşlarında 4 deney grubunda, 4 kontrol grubunda olmak üzere toplam 8 çocukla çalısmıştır. Araştırmanın bulgulanan sonuçlarına göre, deney grubundaki çocukların sosyal işbirliği, sosyal etkileşim, sosyal bağımsızlık gibi sosyal becerilerinin arttığı, içe yönelim ve dışa yönelim davranış problemlerinin azaldığı görülmüştür. Yapılan çalışmada deney ve kontrol grubundaki çocukların Sosyal Beceri Ölçeği; sosyal işbirliği, sosyal etkileşim, sosyal bağımsızlık alt boyutlarına ilişkin ön test puan ortalamaları arasında anlamlı bir fark olmadığı belirlenmiştir. Ayrıca, deney ve kontrol grubundaki çocukların, Problem Davranış Ölçeği; dışa yönelim problemi, içe yönelim alt boyutlarına ilişkin ön test puan ortalamaları arasında da anlamlı bir fark olmadığı belirlenmiştir. Bu sonuca göre, eğitime başlarken deney ve kontrol grubundaki çocukların, sosyal beceri ve problem davranışları yönünden benzer özelliklere sahip olduğu söylenebilmektedir. Yapılan analizler deney ve kontrol gruplarının aynı evrenden oluşturulduğunu göstermektedir.

Denence 2: Deney grubunda bulunan öğrencilerin, ÇSAÖ-Y öntest-sontest puanları arasında istatistiksel olarak anlamlı farklıllğa ait bulguların tartışılması ve yorumlanması:

Verilerin analizine göre, uygulanan oyun terapisiyle bütünleştirilmiş grupla psikolojik danışma oturumları sonucunda deney grubuna katılan öğrencilerin ÇSAÖ-Y öntest-sontest puanları arasinda istatistiksel olarak anlamlı bir fark bulunmuştur. Fark puanlarının sıra ortalaması ve sira toplamları göz önünde bulundurulduğunda bulgulanan bu fark sonucunda sontest lehine azalma olduğu görülmüştür. $\mathrm{Bu}$ durum bize, oyun terapisiyle bütünleştirilmiş grupla psikolojik danışma oturumlarının etkili olduğunu, oturumlar sonunda deney grubuna katılan öğrencilerin kaygı düzeylerinin azaldığını göstermektedir.

Literatürde yer alan çalışmalara bakıldığında; Candan (2017), 3-10 yaş arası gelişimsel problemlere sahip çocuklar üzerinde yaptığı bir çalışmada, Çocuk Merkezli Oyun Terapisi alan çocukların kayg1, depresyon, dikkat eksikliği, sosyal içe dönüklük problemlerinde, agresif ve saldırgan davranışlarında belirgin azalmalar olduğunu bulgulamıştır. Elde edilen bu bulgunun araştırmanın sonuçlarıyla paralellik gösterdiği görülmektedir.

Bununla birlikte literatürde oyun terapisinin etkililiğini inceleyen çeşitli araştırmalar bulunmaktadır. Yıldız (2015, s. 23), utangaçlık düzeyleri yüksek ikinci ve üçüncü sınıf öğrencileri üzerinde, Wakaba (1983, s. 93) ise kekeleyen çocuklar üzerinde oyun terapisi çalışmalarının etkililiğini incelemişler ve oyun terapisinin etkili olduğunu tespit etmişlerdir. Rahmani ve Moheb (2010, s. 23) de, oyun terapisi çalışmasının etkililiğini tespit etmek amacıyla kreşe giden 30 çocuk üzerinde çalışmışlardır. Çalışmada, on çocukla, on oturumluk oyun terapisinin uygulaması yapılmıştır. Uygulama sonucunda, deney grubunun kayg1 düzeyinin, kontrol grubunun kayg1 düzeyine göre belirgin düzeyde azaldığ1 görülmüştür. Kırk iki sokak çocuğu üzerinde oyun terapisinin etkililiğinin incelendiği bir araştırmada ise oyun terapisinin çocukların öfkelerini kontrol etmede etkili olduğu ve benlik sayg1sı düzeylerini arttırdığı, depresyon ve kayg1 düzeylerini ise azalttığı gözlenmiştir (Baggerly, 2004, s. 31). Elde edilen bulgular incelendiğinde araştırmanın sonuçlarıyla paralellik gösterdiği görülmektedir.

Denence 3: Kontrol grubunda bulunan öğrencilerin ÇSAÖ-Y öntest-sontest puanlar1 arasında istatistiksel olarak anlamlı farklılığın olmadığına dair bulguların tartışılması ve yorumlanması:

Verilerin analizine göre, kontrol grubuna katılan öğrencilerin ÇSAÖ-Y öntest-sontest puanları arasında istatistiksel olarak anlamlı bir fark yoktur. Bu durum oyun terapisi oturumlarına katılmamış olan kontrol grubu öğrencilerinde herhangi bir değişimin olmadığını göstermektedir.

Zorlu (2016, s. 160), Virginia Axline tarafindan kuramsal temelleri oluşturulan "Yönlendirici Olmayan Oyun Terapisi" uygulamasının dikkat eksikliği hiperaktivite bozukluğu belirtileri gösteren çocukların duyguları ve davranışları üzerindeki etkisini incelemiştir. Çalışma deney-kontrol gruplu, ön-test, son-test ve izleme ölçümlerinin yapıldığı tam bir deneysel çalışmadır. Araştırma kapsamında, İstanbul'da bulunan ve ilkokula devam eden öğrencilerden dikkat eksikliği hiperaktivite bozukluğu belirtileri gösteren çocuklar arasından seçilen beşer ögrenciden deney ve kontrol grubu oluşturulmuştur. Deney gruplarına yönlendirici olmayan oyun terapisi uygulanmıştır. Araştırma sonucunda, deney grubundaki öğrencilerin Conners Ölçeği 
ile belirlenen dikkat eksikliği hiperaktivite bozukluğu ile ilişkili duygu ve davranışlarında olumlu yönde gelişme olduğu, kontrol grubu öğrencilerinde ise herhangi bir değişim olmadığı görülmüştür.

Sezici’nin (2013, s. 65) Sosyal Bilişsel Öğrenme Teorisi’ne göre çocukların sosyal, duygusal, davranışsal becerileri üzerinde oyun terapisinin etkisini belirlemek üzere yaptı̆̆ araştırmada, sontest ve tekrar test sonucunda deney ve kontrol grubu içerisindeki çocukların puan ortalamaları arasındaki fark istatistiksel olarak anlamlı bulunmuştur. Deney grubunda bulunan çocukların, alt boyutlardan aldıkları puan ortalamalarının oyun hamuru çalışması sonucunda düzenli olarak arttı̆̆1 görülmüştür. Fakat kontrol grubunda bulunan çocukların son test ile tekrar testteki puan ortalamaları arasında fark bulunmamıştır. Elde edilen bulgular incelendiğinde araştırmanın sonuçlarıyla paralellik gösterdiği görülmektedir.

Denence 4: Deney ve kontrol grubunda bulunan öğrencilerin, ÇSAÖ-Y sontest puanları arasında istatistiksel olarak anlamlı farklılı̆ga ait bulguların tartışılması ve yorumlanması:

Araştırma verilerinin analizleri sonucunda deney ve kontrol grubunda bulunan öğrencilerin, ÇSAÖ-Y sontest puanları arasında istatistiksel olarak anlamlı bir farklılık vardır. Bu sonuç bize, oyun terapisiyle bütünleştirilmiş grupla psikolojik danışma oturumlarına katılan deney grubu öğrencileri ile bu oturumlara katılmayan kontrol grubu öğrencileri arasında fark olduğunu ve oturumlar sonunda deney grubuna katılan öğrencilerin kaygı düzeylerinin azaldığını göstermektedir.

Yapılan bazı araştırmalarda da benzer sonuçlara ulaşılmıştır. Shen (2002, s. 43), deprem yaşayan Tayvan'daki Çinli çocuklarla kısa süreli çocuk merkezli grup oyun terapisi üzerine bir çalışma yapmıştır. Bu çalş̧ma, 8-12 yaş arası 65 çocukla yürütülmüştür. Çalışma sonucunda, deney grubunda yer alan çocuklar kontrol grubunda yer alan çocuklara göre anksiyete ve intihar riskinde anlamlı derecede düşük puan almışlardır. Çelik (2017, s. 30) de yaptı̆̆ bir çalışmada, yaşları 3-10 arasında değişen 32 çocuğa Deneyimsel Oyun Terapisi uygulamıştır. Araştırmada öntest-sontest desenini kullanmıştır. Örneklem grubuna araştırma öncesinde ve sonrasında Çocukluk Çağı Travma Sonrası Duygusal Stres Ölçeğini (PEDS) uygulamış ve çocukların duygusal stres düzeylerini ölçmüştür. Araştırma sonucunda elde edilen bulgulara göre, Deneyimsel Oyun Terapisinin kimsesiz ve korunmaya muhtaç çocukların travmaya bağlı duygusal streslerinde azalmanın görülmesinde etkili olduğu ve travma etkilerinin anlamlı düzeyde çözüme kavuştuğu sonucuna varılmıştır.

Literatür incelendiğinde oyun terapisi çalışmalarının, çocukların duygusal ve davranışsal sorunlarının azaltılmasında ve bu sorunların ortadan kaldırılmasında etkili olduğu görülmektedir. $\mathrm{Bu}$ sonuçlar araştırmanın bulgusunu destekler niteliktedir.

Denence 5: Deney grubunda bulunan öğrencilerin ÇSAÖ-Y ön test puanları ile ÇSAÖ-Y izleme testi puanları arasındaki istatistiksel olarak anlamlı farklıllğa ait bulguların tartışılması ve yorumlanması:

Araştırma verilerinin analizleri sonucunda deney grubuna katılan öğrencilerin ÇSAÖ-Y öntest puanları ile izleme test puanları arasında istatistiksel olarak anlamlı farklılık vardır. Bu durum bize, oyun terapisiyle bütünleştirilmiş grupla psikolojik danışma oturumlannnn etkili olduğunu ve bu oturumlarının etkilerinin de devam ettiğini göstermektedir.

Zorlu (2016, s. 160), "Yönlendirici Olmayan Oyun Terapisi" uygulamasının dikkat eksikliği hiperaktivite bozukluğu belirtileri gösteren çocukların duyguları ve davranışları üzerindeki etkisini incelemiştir. Deney grubunda yer alan öğrencilerin öğretmenleri tarafindan doldurulan Conners Öğretmen Değerlendirme Ölçeğinden aldıkları ön test, son test ve izleme testi puanları Wilcoxon İşaretli Sıralar testi karşılaştırıldığında, ön testler ve son testler arasında anlamlı fark görülmemiş, ancak ön testler ve izleme testleri arasında izleme testi lehine anlamlı fark görülmüştür. Deney grubunda yer alan öğrencilerin ebeveynlerinin doldurduğu Conners ebeveyn dereceleme ölçeği toplam puan, karşı gelme alt ölçeği, bilişsel problemler/dikkatsizlik alt ölçeği, hiperaktivite, sosyal problemler alt ölçeği, kayg1/utangaçl1k alt ölçeği ön test ve izleme testi puanları arasında anlamlı bir farklılık olduğu görülmüştür.

Buna göre uygulanan oyun terapisi yaklaşımlarının yapılan çalışma üzerinde etkisinin olduğu söylenebilir. Bu araştırma sonucunda elde edilen bulguların istatistiksel sonuçları, yurt içinde ve yurt dışında yapilan araştırmaların (Gençer ve Aksoy, 2016, s. 247; Gürleyen, 2016, s. 99; Leblanc ve Ritchie, 2001, s. 156; Knell, 2013, s. 324; Teber, 2015, s. 81) sonuçları ile karşılaştırıldığında sonuçların benzerlikler gösterdiği görülmektedir.

Sonuç olarak, oyun terapisiyle bütünleştirilmiş grupla psikolojik danışmanın ilkokul öğrencilerinin sosyal kayg1 düzeylerini azaltmadaki etkisinin incelendiği bu araştırmada, oyun terapisinin etkili olduğu, 
sosyal kayg1 düzeyinin azaltılmasını kısa sürede gerçekleştirdiği, araştırma bulgularının, alan yazınındaki diğer araştırmaların sonuçlarıyla örtüştüğü görülmüştür. Öğrencilerin öğretmenleri ve anneleri ile yapılan bireysel görüşmeler neticesinde, araştırmada yer alan öğrencilere katk1 sağlandığ1 fark edilmiştir. Araştırmada, sosyal kaygının değerlendirilmesine yönelik olarak her iki oturum sonrasında deney grubundaki öğrencilerin yaptıkları kişisel değerlendirmelerde, öğrencilerin sosyal kaygılarının azalmasında bir istikrarın olduğu da görülmüştür. Oturumlar sonrasında öğretmen ve velilerle yapılan görüşmelerde bunu desteklemiştir. Ayrıca, sontestten elde edilen puanlar da bu farkı teyit etmektedir. Tüm bunlara ek olarak araştırmadan altı ay sonra ortaokula geçen deney grubu öğrencilerine uygulanan izleme testi ile öntest arasındaki farklılığın varlığı da çalışmanın etkisinin uzun dönemli olarak sürdüğünü ve çalışmanın etkililiğini kanıtlamaktadır.

Öğrencilerin sosyal kaygı durumlarına yönelik olarak yapılan bireysel görüşmelerde, öğrencilerin anneleri ve öğretmenlerinin ifadeleri karşılaştırıldığında birbirlerine paralel olarak görüş bildirdikleri görülmüştür. Bildirilen görüsslerde, öğrencilerin hem sınıf içerisinde hem de çevre yaşantılarında sosyal kaygı düzeylerinin azaldığına dair gözlemler dile getirilerek örnekler verilmiştir.

Öğrenciler, oturumlar sürecinde değerlendirildiğinde de, başlangıçta iletişim kurmakta güçlük yaşayan, kendini açmakta zorlanan, sesleri kısık bir şekilde çıkan, konuşurken ellerini ovuşturup bedeni kasılan, kekeleyen, cümle kurmakta zorlanan çocukların, oturumlar ilerledikçe kendilerini açtıkları, göz teması kurarak kendilerini ifade edip duygularını yansıtabildikleri, bunları yaparken rahat ve sakin olabildikleri görülmüştür. Ayrıca öğrencilerin anneleri, çocuklara uygulanan oturumlarla birlikte çocuklarının komşu ve akrabalarının içerisinde daha rahat hareket etmeye başladıklarını, selamlaştıklarını, kendilerine arkadaş bulabildiklerini, sorun yaşadıklarında bunu ifade edebildiklerini belirtmişlerdir. Bununla birlikte, öğrencilerin öğretmenleri, yapılan çalışmayla birlikte öğrencilerin akademik başarı düzeylerinin arttığını, sosyal etkinliklerde rol alarak ön plana çıabildiklerini, arkadaşlık ilişkilerini geliştirdiklerini, derslerde daha fazla söz almaya başladıklarını ifade etmişlerdir. Tüm bu bilgiler ışığında, öğrencilerin anneleri ve sınıf öğretmenlerinin değerlendirmeleri ile araştırma sonuçlarının, birbiriyle tutarlı olduğu görülmekte ve araştırmanın etkili olduğu sonucuna ulaşılmaktadır.

Araştırmada elde edilen bulgular doğrultusunda şu öneriler geliştirilebilir:

Araştırma, sosyal kayg1 yaşayan ilkokul öğrencilerine yönelik oyun terapisiyle bütünleştirilmiş grupla psikolojik danışma oturumlarına katılan deney grubu ile hiç bir müdahalede bulunulmayan yalnızca öntest ve sontest uygulamalarına katılan bir kontrol grubundan meydana gelmiştir. Araştırma dahilinde oluşturulacak bir plasebo kontrol grubu oluşturularak bu gruba sosyal kaygiyla ilgili olmayan etkinlikler yapılabilir ve sonuçlar karşılaştırılabilir.

Programın genellenebilmesi ve etkililiğinin test edilebilmesi ve diğer araştırma sonuçlarıyla karşılaştırılabilmesi için oyun terapisi oturumları daha geniş bir örneklem ve farklı gruplara uygulanabilir.

Grupla psikolojik danışma olarak uygulanan oyun terapisi oturumları bireysel olarak da gerçekleştirilerek sonuçlar karşılaştırılabilir.

\section{Etik Beyan}

“Oyun Terapisiyle Bütünleştirilmiş Grupla Psikolojik Danışmanın İlkokul Öğrencilerinin Sosyal Kayg1 Düzeylerine Etkisi” başlıklı çalışmanın yazım sürecinde bilimsel, etik ve alıntı kurallarına uyulmuş; toplanan veriler üzerinde herhangi bir tahrifat yapılmamış ve bu çalsşma herhangi başka bir akademik yayın ortamına değerlendirme için gönderilmemiştir.

\section{Kaynakça}

Acar, N. V. (2013). Grupla psikolojik danısmada alssttrmalar-deneyler. Ankara: Nobel Yayınevi.

Albano, A. M., DiBartolo, P. M., Heimberg, R. G. ve Barlow, D. H. (1995). Social phobia: Diagnosis, assessment, and treatment. New York: The Guilford Press.

Antony, M. M. ve Swinson, R. P. (2017). The shyness and social anxiety workbook: Proven, step-by-step techniques for overcoming your fear. Oakland: New Harbinger Publications.

Baggerly, J. (2004). The effects of child-centered group play therapy on self-concept, depression, and anxiety of children who are homeless. International Journal of Play Therapy, 13(2), 31-51.

Bal, U., Çakmak, S. ve Uğuz, Ş. (2013). Anksiyete bozukluklarında cinsiyete göre semptom farklilıkları. Arşiv Kaynak Tarama Dergisi, 22(4), 441-459. 
Bratton, S. C., Baggerly, J. N. ve Ray, D. C. (2010). Child-centered play therapy research. DC: American Psychological Association.

Burns, G. W. (2016). Cocuklar ve gençler için 101 tedavi edici öykü. Ankara: Nobel Yaşam.

Cabe, N. (2017). Rahatlama eğitimi: Baloncuklar. H. G. Kadusan ve C. E. Schaefer (Ed.), En popüler 101 oyun terapisi tekniği içinde (ss. 349-364). (N. C. Maral, Çev.) Ankara: Nobel Yaşam.

Candan, S. (2017). 3-10 yaş arast gelişimsel problemleri olan çocuklarda çocuk merkęli oyun terapisinin etkisinin incelenmesi (Yüksek Lisans Tezi). Atatürk Üniversitesi Eğitim Bilimleri Enstitüsü, Erzurum.

Crenshaw, D. A. (2017). Parti şapkalı canavarlar: çocukların korkularını yenmelerini sağlayan çizim stratejileri. H. G. Kadusan ve C. E. Schaefer (Ed.), En popüler 101 oyun terapisi tekniği içinde (ss. 110-113). (N. C. Maral, Çev.) Ankara: Nobel Yaşam.

Çankaya, G. (2014). Cocuklarn oynadıklar oyunlara göre empati ve saldırganlık düzeylerinin incelenmesi (Yüksek Lisans Tezi). İstanbul Üniversitesi Eğitim Bilimleri Enstitüsü, İstanbul.

Çelik, M. (2017). Deneyimsel oyun terapisinin çocuk evlerinde kalmakta olan 3-10 yas grubu çocuklarn çocukluk çăğ travma sonrası duygusal stres düzeyine etkisinin incelenmesi (Yüksek Lisans Tezi). Üsküdar Üniversitesi Sosyal Bilimler Enstitüsü, İstanbul.

Demir, T., Eralp-Demir, D., Türksoy, N., Özmen, E. ve Uysal, Ö. (2000). Çocuklar için sosyal anksiyete ölçeğinin geçerlik ve güvenirliği. Düsünen Adam, 13(1), 42-48.

Doğanay, J. (1998). Anasmifina devam eden çocuklarm ebeveynlerinin çocuk oyun ve oyuncaklar bakkendaki görï̈lerinin incelenmesi (Yüksek Lisans Tezi). Ankara Üniversitesi Fen Bilimleri Enstitüsü, Ankara.

Doherty, J. M. ve Philips, R. D. (2017). Verandadaki salıncakta okuma. H. G. Kadusan ve C. E. Schaefer (Ed.), En popüler 101 oyun terapisi tekniği içinde (ss. 36-39). (N. C. Maral, Çev.) Ankara: Nobel Yaşam.

Eren-Gümüş, A. (2016). Sosyal kaygının benlik saygisına ve işlevsel olmayan tutumlara göre yordanması. Türk Psikolojitk Danısma ve Rebberlik Dergisi, 3(26), 63-75.

Erkan, Z., Güçray, S. ve Çam, S. (2002). Ergenlerin sosyal kayg1 düzeylerinin ana baba tutumları ve cinsiyet açısından incelenmesi. Cukurova Üniversitesi Sosyal Bilimler Enstitüsü Dergisi, 10(10), 64-75.

Gençer, A. A. ve Aksoy, A. B. (2016). Anne çocuk etkileşiminde farklı bir yaklaşım: Theraplay oyun terapisi. Psikiyatride Güncel Yaklassımlar-Current Approaches in Psychiatry, 8(3), 244-254.

Gürleyen, B. (2016). Mentalization and symbolization and symbolization in psychodynamic play therapy process: An empirical investigation of the effect of mentalizing interventions on symbolic play and mentalization (Yüksek Lisans Tezi). İstanbul Bilgi Üniversitesi Sosyal Bilimler Enstitüsü, İstanbul.

Halmatov, S. (2017). Oyun terapisinde pratik teknikler. Ankara: Pegem Akademi.

Karasar, N. (2009). Bilimsel araștırma yöntemi. Ankara: Nobel Yayın Dağıtım.

Kaya, A. ve Saçkes, M. (2012). Benlik saygısı geliştirme programının ilköğretim 8. Sınıf öğrencilerinin benlik saygıs1 düzeylerine etkisi. S. Erkan ve A. Kaya (Ed.), Deneysel olarak sinanmıs grupla psikolojik danısma ve rebberlik programlar I içinde (ss. 149-228). Ankara: Pegem Akademi.

Knell, S. M. (2013). Bilişsel davranışçı oyun terapisi. C. E. Schaefer (Ed.), Oyun terapisinin temelleri içinde (ss. 313-328). (B.T. Özkaya, Çev.) Ankara: Nobel Akademik Yayıncılık.

Koçkaya, S. (2016). Okul öncesi çocuklarmm çekingenlik davranışlar üzerine oyun terapisi uygulamalarmm etkisi (Yüksek Lisans Tezi). Dokuz Eylül Üniversitesi Eğitim Bilimleri Enstitüsü, İzmir.

La Greca, A. M., Dandes, S. K., Wick, P., Shaw, K. ve Stone, W. L. (1988). Development of the social anxiety scale for children: Reliability and concurrent validity. Journal of Clinical Child Psychology, 17(1), 84-91.

Landreth, G. L. (2012). Play therapy: The art of the relationship. New York: Routledge.

Leblanc, M. ve Ritchie, M. (2001). A meta-analysis of play therapy outcomes. Counselling Psychology Quarterly, 14(2), 149-163.

Liberman, J. M. (2015). Masal terapi. (Çev: İ. Erdener). İstanbul: Doğan Novus.

Linden, C. (2017a). Ağırlıklar ve balonlar. H. G. Kadusan ve C. E. Schaefer (Ed.), En popüler 101 oyun terapisi tekniği içinde (ss. 102-106). (N. C. Maral, Çev.) Ankara: Nobel Yaşam.

Linden, C. (2017b). Lensler. H. G. Kadusan ve C. E. Schaefer (Ed.), En popüler 101 oyun terapisi tekniği içinde (ss. 270274). (N. C. Maral, Çev.) Ankara: Nobel Yaşam.

Özyürek, A. ve Demiray, K. (2010). Yurtta ve ailesi yanında kalan ortaöğretim öğrencilerinin kayg1 düzeylerinin karşılaştırılması. Doğus Üniversitesi Dergisi, 11(2), 247-256.

Rahmani, P. ve Moheb, N. (2010). The effectiveness of clay therapy and narrative therapy on anxiety of pre-school children: A comparative study. Procedia Social and Behavioral Sciences, 5, 23-27.

Robinson, S. (2011). What play therapists do within the therapeutic relationship of humanistic/non-di rective play therapy. Pastoral Care in Education Aquatic Insects, 29(3), 207-220.

Saltık, N. (2018). Kadın konukevlerinde kalan cocuklarda oyun terapisinin sosyal beceri ve problem davranıslara etkisinin incelenmesi (Yüksek Lisans Tezi). Ankara yıldırım Beyazıt Üniversitesi Sağlık Bilimleri Enstitüsü, Ankara.

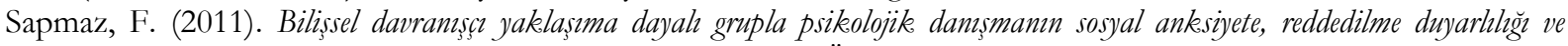
kişilerarası duyarlılk üzerine etkisi (Doktora Tezi). Sakarya Üniversitesi Eğitim Bilimleri Enstitüsü, Sakarya.

Schaefer, C. E. ve Drewes, A. A. (2010). The therapeutic powers of play and play therapy. A. A. Drewes ve C. E. Schaefer (Eds.). In School based play therapy (pp. 3-16). New Jersey: John Wiley \& Sons, Inc.

Schaefer, C. E. ve Drewes, A. A. (2013). Oyunun ve oyun terapisinin terapötik güçleri. C. E. Schaefer (Ed.), Oyun terapisinin temelleri içinde (ss. 15-25). (B.T. Özkaya, Çev.) Ankara: Nobel Akademik Yayıncılık. 
Schottelkorb, A. A., Swan K. L., Jahn, L., Haas, S. ve Hacker, J. (2015). Effectiveness of play therapy on problematic behaviors of preschool children with somatization. Journal of Child and Adolescent Counseling, 1(1), 3-16.

Sertelin-Mercan, Ç. (2007). Bilisssel davranış̧ yaklaşımla bütünleştirilmiş sosyal beceri eğitiminin ergenlerin sosyal kaygı düzeyine etkisi (Doktora Tezi). İstanbul Üniversitesi Sosyal Bilimler Enstitüsü, İstanbul.

Sezici, E. (2013). Okul öncesi çocuklarda oyun terapisinin sosyal yetkinlik ve davranıs yönetimine etkisi (Doktora Tezi). Marmara Üniversitesi Sağlık Bilimleri Enstitüsü, İstanbul.

Shen, Y. J. (2002). Short-term group play therapy with Chinese earthquake victims: Effects on anxiety, depression and adjustment. International Journal of Play Therapy. 11(1), 43-63.

Sprague, D. G. (2017). Kuklalarla psikodrama. H. G. Kadusan ve C. E. Schaefer (Ed.), En popüler 101 oyun terapisi tekniği içinde (ss. 237-241). (N. C. Maral, Çev.) Ankara: Nobel Yaşam.

Stickney, E. M. (2017). Nasıl yapıyorum? Kişisel değerlendirme tekniği. H. G. Kadusan ve C. E. Schaefer (Ed.), En popüler 101 oyun terapisi tekniği içinde (ss. 123-125). (N. C. Maral, Çev.) Ankara: Nobel Yaşam.

Sümer, Z. H. (2012). Sosyal beceri eğitiminin ilköğretim öğrencilerinin algilanan sosyal beceri boyutlarına ve sosyometrik statülerine etkisi. S. Erkan ve A. Kaya (Ed.), Deneysel olarak sinanmus grupla psikolojik damısma ve rebberlik programlar I içinde (ss. 1-41). Ankara: Pegem Akademi.

Teber, M. (2015). Çocuk merkę̧li oyun terapisinin çocuklarda görülen davranıs sorunlarnın çözümüne etkisi (Yüksek Lisans Tezi). Hasan Kalyoncu Üniversitesi Sosyal Bilimler Enstitüsü, Gaziantep.

Wakaba, Y. (1983). Group play therapy for Japanese children who stutter. Journal of Fluency Disorders, 8, 93-118.

Yazman, Ü. (t.y). Başar için sosyal fobiyi yenmek şart. Erişim: 15 Ekim 2017, http://www.kigem.com/basari-icin-sosyalfobiyi-yenmek-sart.html

Yerlikaya, Z. (2011). Sosyal fobi ve bir psikodrama uygulaması. Erişim: 10 Ekim 2017, http:/ / www.terapiportali.com/?page=blogpost\&yid=128\&url=sosyal-fobi-ve-psikodrama-terapisi

Yıldız, C. (2015). Oyun terapisiyle bütünlestirilmiş grup terapisinin çocuklarn utangaçllk düzeylerine etkisi (Yüksek Lisans Tezi). Beykent Üniversitesi Sosyal Bilimler Enstitüsü, İstanbul.

Yılmaz, G. (2013). Ergenlerde mobil telefon bağımhlĭğmn sosyal anksiyeteye etkisinin baz̨ değğskenlere göre incelenmesi (Yüksek Lisans Tezi). Nişantaşı Üniversitesi Sosyal Bilimler Enstitüsü, İstanbul.

Yılmaz, B. Ş. ve Duy, B. (2013). Psiko-eğitim uygulamasının kız öğrencilerin benlik saygısı ve akılcı olmayan inançları üzerine etkisi. Türk Psikolojik Damısma ve Rehberlik Dergisi, 4(39), 68-81.

Zorlu, A. (2016). Yönlendirici olmayan oyun terapisinin dikeat eksikliği biperaktivite bozukluğu belirtili çocuklarn duygu ve davranışlar üzerindeki etkisinin incelenmesi (Doktora Tezi). İstanbul Üniversitesi Eğitim Bilimleri Enstitüsü, İstanbul.

\section{EXTENDED ABSTRACT}

Social anxiety is a kind of anxiety which the child lives through and should be seen considerable. Social anxiety is related to fear of negative evaluation and distress in social environments (Albano, DiBartolo, Heimberg, \& Barlow, 1995, p. 398). Developmental studies on children have shown that social anxiety is an important form of anxiety that starts in primary school and continues in adolescence. (Demir, Eralp-Demir, Türksoy, Özmen, \& Uysal, 2000, p. 43). To Eren-Gümüş (2016, p. 64), having a social anxiety problem and the failure to resolve this problem has a significant impact on child's future life. Early detection of this problem will be more helpful in helping both short and effective psychological assistance in the early period.

In studies conducted with children with high levels of social anxiety, cognitive behavioral treatment methods and game therapy techniques can give positive results (Baggerly, 2004, p. 31; Knell, 2013, p. 324; Sezici, 2013, p. 58). With play therapy children who have high levels of anxiety will be able to express themselves in a safe environment, experience the behaviors they are concerned with and gain positive behaviors (Doğanay, 1998, p. 1).

In this study, group psychological counseling sessions integrated with play therapy were applied to the group of primary school students who had social anxiety. At the end of the research, the effectiveness of the sessions will be determined. Thus, it is thought that through the sessions, students' social anxiety levels will be reduced and thus students will contribute to their academic, social and emotional development.

The aim of this study is to search the effect of group counselling integrated with play therapy on the levels of social anxiety of primary school students. Hypothesis developed for this purpose have been tested.

In this study, experimental design with pretest-posttest control group was used. The experimental group had group counseling sessions integrated with play therapy. The independent variable of the study 
is psychological group counseling sessions integrated with play therapy and the dependent variable is the social anxiety levels of the primary school students.

The study population is the fourth grade students of a primary school in the 2017-2018 academic year in the Selcuklu district of Konya. ÇSAÖ-Y (Demir et al, 2000) was applied to the students in the study population. Both experimental group and control group consist of students, four girls and four boys for each, who were assigned by neutral neutral assignment among the students who have the highest level of social anxiety.

In order to obtain socio-demographic information about the students, Personal Information Form and to determine socio-demographic information Social Anxiety Scale for Children-Revised Form (ÇSAÖ-Y) were used. The reliability and validity study of ÇSAÖ-Y was conducted by Demir et al (2000, p. 42). In this scale; with 18 questions, five-point likert type and depends on self-report, the score is between 18-90. ÇSAÖ-Y is seen as a valid and reliable tool for measuring social anxiety of children and adolescents.

In order to determine the research subjects, all of the students in the study population were administered ÇSAÖ-Y as a pre-test. Accordingly, the lowest score obtained from the scale was 19 and the highest score was 80. Taking the expert opinion who developed the scale, the students who took 59 points and above formed the nose of the study. According to the information in the personal information form, the opinions of the class teachers and the families, 16 students with high social anxiety level were determined. The students were randomly assigned to the experimental and control groups. As a result, eight students in experimental group (four girls, four boys) and eight students (four girls, four boys) in control groups were included.

The experimental group was applied group psychological counseling sessions integrated with play therapy by the researcher. On the creation of sessions, play therapy and group sessions based on cognitive behavioral approach were benefited (Koçkaya, 2016, p. 37; Sapmaz, 2011, p. 10; Sertelin-Mercan, 2007, p. 100; Sezici, 2013, p. 58; Y1ldı, 2015, p. 24). Besides, the age and developmental characteristics of the students were taken into consideration. Each session was administered as 40 minutes once a week for two months. After completion of the sessions, the posttest was applied to the experimental and control groups. Six months after the study, experimental group students were followed-up.

As a result of the analysis of the data, no statistically significant difference was found between either pre-test scores of the experimental and control groups or the pretest and posttest scores of the experimental groups. A statistically significant difference was found between both pretest and posttest scores of the experimental group and the posttest scores of the experimental and control groups. Also, significant difference was found between the pretest scores and the follow-up test scores of the experimental group.

In this study, it was seen that play therapy reduced the social anxiety level in a short time and the research findings were consistent with the results of other studies in the literature. As a result of the individual interviews conducted with the mothers of students and the class teachers of students, it was noticed that they contributed to the students. In the research, in the personal assessments of students, it is seen that there is stability in decreasing the social anxiety of students. Besides, this difference is confirmed by the scores obtained from the posttest. The existence of the difference between the pretest and the follow-up test also proves the long-term effect of the study and the effectiveness of the study.

Within the research, a placebo control group can be created and activities that are not related to social anxiety can be done and the results can be compared. Play therapy sessions can be applied to a larger sample and to different groups. Play therapy sessions can be performed individually and the results are comparable. 